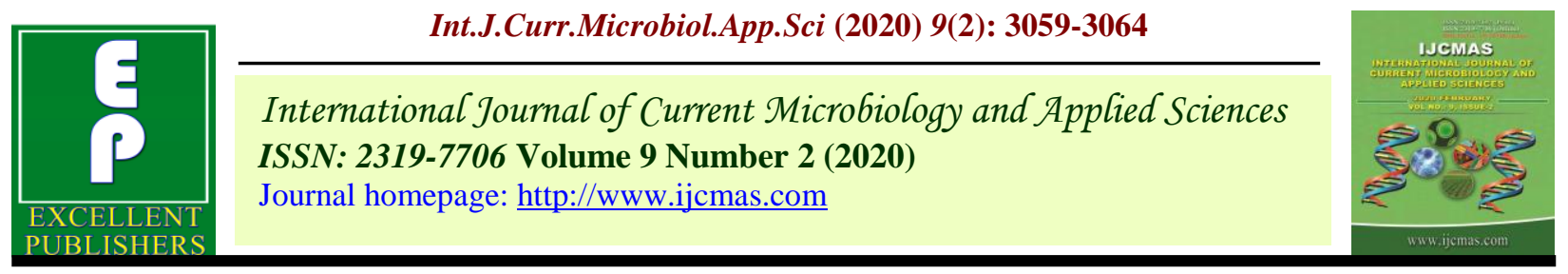

Original Research Article

https://doi.org/10.20546/ijcmas.2020.902.352

\title{
Vertical Distribution of Available Macro and Micronutrients in Cotton Growing Soils of Nanded District, Maharashtra, India
}

\author{
M. K. Ghode ${ }^{1 *}$, P. H. Vaidya ${ }^{2}$, Y. S. Pawar ${ }^{1}$, S. A. Adkine ${ }^{2}$ and R. R. Bagmare ${ }^{3}$ \\ ${ }^{1}$ Department of Soil Science and Agricultural Chemistry, College of Agriculture, Latur, India \\ ${ }^{2}$ Department of Soil Science and Agricultural Chemistry, VNMKV, Parbhani, India \\ ${ }^{3}$ Departmentof Soil Science and Agricultural Chemistry, College of Agriculture, \\ Parbhani, India \\ *Corresponding author
}

Keywords

Available N, P, K and $\mathrm{S}$, Available micronutrients, cotton

Article Info

Accepted:

20 January 2020

Available Online:

10 February 2020

\section{A B S T R A C T}

Seven representative soil profiles from different physiographic unit of Nanded district were selected and studied to assess the nutrient status of soils of cotton growing region of Nanded district of Maharashtra. Horizon wise nutrient status in soil profiles of Nanded area revealed that the soils were very low to low in available nitrogen (75.26 to $225.79 \mathrm{~kg} \mathrm{ha}^{-1}$ ), low to medium in available phosphorus (3.5 to $17.92 \mathrm{~kg} \mathrm{ha}^{-1}$ ), medium to high in available potassium (197.6 to $535.3 \mathrm{~kg} \mathrm{ha}^{1}$ ) and low to high in available sulphur $\left(8.75\right.$ to $\left.36.5 \mathrm{mgkg}^{-1}\right)$. The DTPA extractable available micronutrients $\mathrm{Zn}, \mathrm{Cu}, \mathrm{Mn}, \mathrm{Fe}$ and $\mathrm{B}$ ranged from 0.224 to $1.18 \mathrm{mgkg}^{-1}$, 0.86 to $4.946 \mathrm{mgkg}^{-1}, 4.13$ to $27.09 \mathrm{mgkg}^{-1}, 10.03$ to $21.92 \mathrm{mgkg}^{-1}$ and 0.21 to $1.32 \mathrm{mgkg}^{-1}$ (weighted mean) soil, respectively. Soils were very low to low in available nitrogen, low to medium in available phosphorus and medium to high available potassium and low to high in available sulphur in the surface horizons and deficient to sufficient in $\mathrm{Zn}$ and sufficient in available $\mathrm{Cu}, \mathrm{Fe}, \mathrm{Mn}$ and $\mathrm{B}$ in the surface layers of the profiles.

\section{Introduction}

Nanded is one of the district of Maharashtra states which, belongs to sub-tropical region, with an average annual rainfall $890 \mathrm{~mm}$. The soils of Nanded are formed from weathering of Deccan basalt rock which is rich in $\mathrm{Ca}, \mathrm{Mg}$ and carbonates but poor in $\mathrm{N}, \mathrm{P}$, and $\mathrm{K}$. The rainfed cotton is frequently grown mostly in shrink-swells of central India, southern states and Gujarat. These soils are generally productive, but difficult to manage. In Marathwada, cotton is grown predominantly as a rainfed crop in Vertisols (black or regur) and associated soils. The soil fertility status exhibits the status of different soils with 
regard to amount and availability of nutrients essential for plant growth. The crop growth and yield largely depend upon potential of soil resources and their characteristic provides water, nutrients and anchorage for the growth and yield of crops. The available macro and micronutrients in the soil profiles aid in determining the soil potential, which are essential for better scientific utilization of crop growth (Rajeshwar and Ramulu, 2016). Micronutrient plays a vital role in maintaining soil health and also productivity of crops. These are needed in very small amounts. The soil must supply micronutrients for desired growth of plants and synthesis of human food. However, exploitive nature of modern agriculture involving use of organic manures and less recycling of crop residues are important factors contributing towards accelerated exhaustion of micronutrients from the soil. The deficiencies of micronutrients have become major constraints to productivity, stability and sustainability of soils (Vijayakumar, 2011).

The deficiencies of micronutrients have become major restriction to productivity, stability and sustainability of soils (Deshpande and Salunkhe, 2013). In order to provide a base line data and information, the present study is taken up in soils of Nanded district of Maharashtra.

\section{Materials and Methods}

Geographically Nanded district of Maharashtra state is located between 180 15 'to $19055^{\prime}$ 'North Latitude and 770 07'to 780 15' East Longitude with the total geographic area is about 10,528 sq. Kms. Nanded district is located exactly in between 18001 ' 35 " to 18025 ' 49" North latitude and $75055^{\prime} 36$ " to $76019^{\prime} 10$ " East longitude at an altitude of 640 to $660 \mathrm{~m}$ above MSL. The total geographical area is 10,528 sq. Kms. In the area received mean annual rainfall of 873 $\mathrm{mm}$ and mean maximum and mean minimum temperature are $36.6{ }^{0} \mathrm{C}$ and $21.53^{\circ} \mathrm{C}$ respectively. The area has Ustic soil moisture regime, Hyperthermic temperature regime and length of growing period is 149 days. Seven representative pedons were selected from different physiographic unit of the study area. $\mathrm{EC}, \mathrm{pH}$, organic carbon and $\mathrm{CaCO}_{3}$ were determined by standard procedure (Jackson, 1973). Available $\mathrm{N}$ in the samples was estimated by alkaline permanganate method. The available $\mathrm{K}$ was determined in neutral normal ammonium acetate [1 $\mathrm{N} \mathrm{CH}_{3} \mathrm{CooNa}$ extract of soil using flame photometer. Available sulphur was determined by using spectrophotometer outlined by William and Steinberg (1969). The available $\mathrm{Cu}$ and $\mathrm{Zn}$ in soil samples were extracted with DTPA [0.005 M DTPA+0.01 M $\quad \mathrm{CaCl} 2+0.1 \quad \mathrm{M}$ triethanolamine, $\mathrm{pH} 7.3$ ] as per method described by Lindsay and Norvell (1978) concentration of $\mathrm{Cu}$ and $\mathrm{Zn}$ in the DTPA extracts was determined using atomic absorption spectrophotometer. Available boron was determined as per the standard procedure by Berger and Trang (1939).

\section{Results and Discussion}

\section{Soil physico-chemical properties of study area}

All the pedons studied were slightly (7.2) to moderately alkaline (8.5) in nature in reaction and appear to be related with parent materials, rainfall and topography (Thangaswamy et al., 2005). The $\mathrm{pH}$ of the soil was decreased with increasing altitude. The increasing trend in $\mathrm{pH}$ with depth could be due to increase in accumulation of exchangeable $\mathrm{Na}^{+}$and $\mathrm{CaCO}_{3}$ ). This is due to leaching of appreciable amount of exchangeable bases. The low E.C values varied from $\left(0.1\right.$ to $\left.0.4 \mathrm{dSm}^{-1}\right)$. The organic carbon content varies from low to high (0.1 to 0.9$)$ was decreased with depth. The $\mathrm{CaCO}_{3}$ content in soils ranged from 5.6 to 
36.1 per cent indicating soils are calcareous in nature. High $\mathrm{CaCO}_{3}$ affects the physical and chemical properties of soil and which has a great influence on crop production under rainfed condition.

\section{Nutrient status and soil fertility}

\section{Available macronutrients}

The soil fertility status exhibits the status of different soils with regard to amount and availability of nutrients essential for plant growth. The available nitrogen content of all the pedons (Table 1) were very low to low in range varied from 75.26 to $225.79 \mathrm{~kg} \mathrm{ha}^{-1}$ throughout the depth. However, available $\mathrm{N}$ content was found to be maximum in surface horizon and decreased regularly with soil depth, which might be due to the confinement of falling of plant residues and debris and rhizosphere of plants and might be due to decreasing trend of organic carbon with depth. Similar results were found by Prasuna et al., (1992) and Rajeshwar And Ramulu, 2016.

The available phosphorus content was low to medium in the horizon of the pedons varied from 3.5 to $17.92 \mathrm{~kg} \mathrm{ha}^{-1}$. However, the highest available $\mathrm{P}$ was observed in the surface horizons and decreased regularly with depth. The reason for higher $\mathrm{P}$ in surface horizon might possibly be the confinement of crop cultivation to the rhizosphere and supplementing of the depleted phosphorus through external sources i.e. fertilizers. Similar results were found by Thangaswamy et al., (2005) and Rajeshwar and Ramulu, 2016. The content of available $\mathrm{K}$ in all the pedons were medium to high varied from 197.6 to $535.3 \mathrm{~kg} \mathrm{ha}^{-1}$. The highest available $\mathrm{K}$ content was noticed in the surface horizons and showed decreasing trend with depth. This could be attributed to more intensive weathering, release of labile-K from organic residues, application of $\mathrm{K}$ fertilizers and upward translocation of $\mathrm{K}$ from lower depths along with capillary rise of ground water. Similar results were found by $\mathrm{Pal}$ and Mukhopadyay (1992) and Vertical distribution of zinc exhibited little variation with depth considering $0.60 \mathrm{mg} \mathrm{kg}^{-1}$ as critical level (Lindsay and Norvell, 1978). These soils were deficient to sufficient in surface layers and deficient in sub surface layers of all the profiles which might be due to accumulation of comparatively less or more amount of organic matter in surface layers than subsurface layers as reported by Jalali et al., (1989) and Nayak et al., (2000). The content of sulphur in these soils in the ranged from 8.75 to $36.5 \mathrm{mg} \mathrm{kg}^{-1}$. Ravte (2008) analyzed the soils of Ausa and Nilanga tahsils of Latur district and reported that the available sulphur content in these soils in the ranged from 3.62 to $84.61 \mathrm{mg} \mathrm{kg}^{-1}$.

\section{Available micronutrients}

The DTPA extractable available $\mathrm{Zn}$ content varied from 0.224 to $1.180 \mathrm{mg} \mathrm{kg}^{-1}$ soil (Table1). Vertical distribution of zinc exhibited little variation with depth considering $0.60 \mathrm{mg} \mathrm{kg}^{-1}$ as critical level (Lindsay and Norvell, 1978). These soils were deficient to sufficient in surface layers and deficient in sub surface layers of all the profiles which might be due to accumulation of comparatively less or more amount of organic matter in surface layers than subsurface layers as reported by Jalali et al., (1989) and Nayak et al., (2000) and Rajeshwar And Ramulu, 2016. All the pedons were found to be sufficient in available $\mathrm{Cu}$ content $\left(0.86\right.$ to $\left.4.946 \mathrm{mg} \mathrm{kg}^{-1}\right)$ as all the values were well above the critical limit of $0.20 \mathrm{mg} \mathrm{kg}^{-1}$ soil as suggested by Lindsay and Norvell (1978). The available copper was more in surface layers and decreased with depth, which might be due to its association with organic carbon affecting it availability in surface layers (Rajeshwar and Ramulu, 2016). 
Table.1 Soil physico-chemical properties and available nutrient status of the study area

\begin{tabular}{|c|c|c|c|c|c|c|c|c|c|c|c|c|c|c|}
\hline Horizon & $\begin{array}{l}\text { Depth } \\
\text { (cm) }\end{array}$ & pH & $\mathbf{E C}\left(\mathbf{d S m}^{-1}\right)$ & $\begin{array}{l}\text { OC } \\
(\%)\end{array}$ & $\begin{array}{c}\mathrm{CaCO}_{3} \\
(\%)\end{array}$ & $\begin{array}{c}\mathbf{N} \\
\left(\mathrm{kg} \mathrm{ha}^{-1}\right)\end{array}$ & $\begin{array}{c}\mathrm{P}_{2} \mathrm{O}_{5} \\
\left(\mathrm{~kg} \mathrm{ha}^{-1}\right)\end{array}$ & $\begin{array}{c}\mathrm{K}_{2} \mathrm{O} \\
\left(\mathrm{kg} \mathrm{ha}^{-1}\right)\end{array}$ & $\begin{array}{c}\mathrm{S} \\
\left(\mathbf{m g k g}^{-1}\right)\end{array}$ & $\begin{array}{c}\mathbf{F e} \\
\left(\mathrm{mgkg}^{-1}\right)\end{array}$ & $\underset{\left(\text { mgkg- }^{1}\right)}{\operatorname{Mn}}$ & $\begin{array}{c}\mathrm{Zn} \\
\left(\mathrm{mg} \mathrm{kg}^{-1}\right)\end{array}$ & $\begin{array}{c}\mathrm{Cu} \\
\left(\mathrm{mg} \mathrm{kg}^{-1}\right)\end{array}$ & $\begin{array}{c}\text { B } \\
\left(\mathrm{mgkg}^{-1}\right)\end{array}$ \\
\hline \multicolumn{15}{|c|}{ Pedon 1 Shri. Ambadas Jangilwad, Village-Chenapur, Tq. Ardhapur, Dist. Nanded (Typic Haplustepts) } \\
\hline Ap & $0-17$ & 7.9 & 0.3 & 0.4 & 08.5 & 150.2 & 17.9 & 393.1 & 36.5 & 11.6 & 12.14 & 1.18 & 3.416 & 0.41 \\
\hline $\mathbf{B w}_{1}$ & $17-33$ & 8.1 & 0.2 & 0.4 & 14.2 & 137.6 & 13.5 & 310.3 & 22.5 & 12.4 & 14.29 & 0.314 & 3.378 & 0.39 \\
\hline $\mathbf{B w}_{2}$ & $33-45$ & 8.1 & 0.2 & 0.5 & 11.3 & 137.6 & 4.0 & 324.2 & 27.5 & 10.9 & 16.87 & 0.424 & 2.616 & 0.35 \\
\hline $\mathbf{C k}_{1}$ & $45-60$ & 8.2 & 0.3 & 0.1 & 27.9 & 125.1 & 7.0 & 257.6 & 16.5 & 10.8 & 16.92 & 0.226 & 2.774 & 0.24 \\
\hline $\mathbf{C k}_{2}$ & $60-80$ & 8.2 & 0.3 & 0.1 & 36.1 & 112.5 & 7.1 & 182.6 & 20.0 & 10.1 & 19.17 & 0.248 & 3.268 & 0.23 \\
\hline \multicolumn{15}{|c|}{ Pedon 2 Shri. Gajanan Gore, Village-Pingali, Tq. Hadgaon, Dist. Nanded (Typic Haplustepts) } \\
\hline Ap & $0-12$ & 8.0 & 0.3 & 0.7 & 16.2 & 125.4 & 7.6 & 284.3 & 27.5 & 13.1 & 15.84 & 0.276 & 4.076 & 1.01 \\
\hline $\mathbf{B w}_{1}$ & $12-27$ & 7.9 & 0.3 & 0.6 & 17.2 & 112.9 & 7.3 & 289.7 & 28.7 & 11.6 & 17.77 & 0.242 & 3.794 & 0.79 \\
\hline $\mathbf{B w}_{2}$ & $27-40$ & 8.0 & 0.3 & 0.6 & 12.5 & 112.9 & 6.8 & 273.5 & 13.7 & 13.2 & 20.59 & 0.308 & 3.528 & 0.82 \\
\hline $\mathbf{C k}_{1}$ & $40-55$ & 8.1 & 0.4 & 0.4 & 25.4 & 100.3 & 3.5 & 210.1 & 15.0 & 11.1 & 18.19 & 0.254 & 1.996 & 0.37 \\
\hline $\mathrm{Ck}_{2}$ & $55-65$ & 8.1 & 0.3 & 0.4 & 26.4 & 87.8 & 4.3 & 223.6 & 17.5 & 11.2 & 15.84 & 0.340 & 1.908 & 0.35 \\
\hline \multicolumn{15}{|c|}{ Pedon 3 Shri. Vishnu Suryawanshi, Village-Hadsani, Tq. Hadgaon, Dist. Nanded (Typic Haplusterts) } \\
\hline Ap & $0-18$ & 7.8 & 0.2 & 0.8 & 10.7 & 175.2 & 10.7 & 380.8 & 31.2 & 14.17 & 06.07 & 0.988 & 4.38 & 1.32 \\
\hline $\mathrm{Bw}_{2}$ & $18-32$ & 7.8 & 0.2 & 0.8 & 09.5 & 162.7 & 11.6 & 344.0 & 31.5 & 13.51 & 06.15 & 0.768 & 4.402 & 1.23 \\
\hline Bss $_{1}$ & $32-65$ & 7.9 & 0.2 & 0.7 & 05.6 & 150.2 & 5.4 & 321.8 & 16.2 & 13.91 & 10.08 & 0.328 & 3.96 & 1.09 \\
\hline $\mathrm{Bss}_{2}$ & $65-100$ & 7.9 & 0.3 & 0.7 & 06.1 & 150.2 & 6.3 & 319.6 & 8.7 & 14.84 & 06.06 & 0.224 & 2.952 & 0.78 \\
\hline $\mathbf{C r}$ & $100-115$ & 7.8 & 0.2 & 0.6 & 13.6 & 100.3 & 7.2 & 176.9 & 16.2 & 12.82 & 05.23 & 0.358 & 2.706 & 0.71 \\
\hline \multicolumn{15}{|c|}{ Pedon 4 Shri. Mukund Hanawate, Village-Borgadi, Tq. Himayatnagar, Dist. Nanded (Typic Haplustepts) } \\
\hline Ap & $0-25$ & 7.2 & 0.3 & 0.9 & 08.1 & 125.4 & 12.5 & 392.7 & 20.0 & 17.47 & 14.33 & 0.582 & 2.506 & 0.63 \\
\hline Bw & $25-35$ & 7.7 & 0.3 & 0.8 & 09.4 & 163.1 & 7.6 & 315.4 & 18.75 & 15.76 & 27.09 & 0.482 & 2.462 & 0.59 \\
\hline $\mathbf{C k}_{1}$ & $35-56$ & 7.8 & 0.4 & 0.5 & 29.0 & 87.8 & 3.5 & 213.7 & 16.25 & 11.78 & 09.88 & 0.496 & 2.62 & 0.34 \\
\hline $\mathrm{Ck}_{2}$ & $56-70$ & 7.9 & 0.4 & 0.3 & 30.6 & 75.2 & 7.7 & 197.3 & 20.0 & 11.83 & 14.55 & 0.660 & 2.648 & 0.29 \\
\hline \multicolumn{15}{|c|}{ Pedon 5 Shri. Dayal Giri, Village-WarangTakali, Tq. Himayatnagar, Dist. Nanded (Calcic Haplusterts) } \\
\hline Ap & $0-17$ & 7.9 & 0.2 & 0.5 & 08.2 & 175.6 & 15.2 & 464.8 & 17.5 & 21.92 & 08.90 & 0.646 & 1.416 & 0.87 \\
\hline $\mathrm{Bw}_{1}$ & $17-35$ & 7.5 & 0.1 & 0.5 & 18.6 & 150.5 & 13.4 & 408.5 & 11.3 & 21.76 & 08.08 & 0.50 & 1.298 & 0.83 \\
\hline $\mathrm{Bw}_{2}$ & $35-60$ & 7.9 & 0.1 & 0.4 & 21.0 & 150.5 & 15.2 & 394.6 & 11.2 & 20.16 & 08.97 & 0.446 & 1.420 & 0.81 \\
\hline Bss & $60-90$ & 7.9 & 0.1 & 0.6 & 05.3 & 225.8 & 10.2 & 369.0 & 12.5 & 17.49 & 08.63 & 0.420 & 0.996 & 0.76 \\
\hline $\mathbf{C k}_{1}$ & $90-113$ & 7.6 & 0.4 & 0.4 & 26.6 & 150.5 & 9.8 & 208.8 & 12.5 & 10.82 & 07.56 & 0.358 & 0.984 & 0.56 \\
\hline $\mathbf{C k}_{2}$ & $113-120$ & 8.0 & 0.4 & 0.2 & 24.0 & 137.9 & 5.4 & 210.9 & 13.7 & 11.41 & 07.32 & 0.520 & 0.86 & 0.49 \\
\hline \multicolumn{15}{|c|}{ Pedon 6 Shri. Baban Chakote, Village-Umari, Tq.Hadgaon, Dist. Nanded (Typic Ustorthents) } \\
\hline Ap & $0-17$ & 8.0 & 0.4 & 0.3 & 11.5 & 125.4 & 12.5 & 260.0 & 13.7 & 10.84 & 22.22 & 0.740 & 1.242 & 0.35 \\
\hline Ac & $17-47$ & 8.1 & 0.3 & 0.4 & 35.9 & 75.2 & 7.6 & 115.1 & 16.2 & 10.32 & 20.87 & 0.428 & 1.238 & 0.33 \\
\hline $\mathrm{Cr}$ & $47-70$ & 8.1 & 0.1 & 0.2 & 31.3 & 75.2 & 5.5 & 109.7 & 17.5 & 10.03 & 19.75 & 0.282 & 1.484 & 0.21 \\
\hline \multicolumn{15}{|c|}{ Pedon 7 Dhiraj Kadam, Village-Koli, Tq. Hadgaon, Dist. Nanded (Calcic Haplusterts) } \\
\hline Ap & $0-16$ & 7.7 & 0.3 & 0.5 & 15.0 & 157.9 & 13.4 & 544.8 & 31.2 & 12.04 & 06.09 & 0.764 & 4.946 & 0.56 \\
\hline $\mathbf{B w}_{1}$ & $16-35$ & 8.0 & 0.3 & 0.5 & 16.2 & 137.9 & 17.0 & 524.3 & 13.7 & 12.21 & 06.18 & 0.796 & 4.61 & 0.53 \\
\hline Bss $_{1}$ & $35-65$ & 8.1 & 0.2 & 0.4 & 13.1 & 100.3 & 17.0 & 176.5 & 16.2 & 15.07 & 9.89 & 0.344 & 3.262 & 0.64 \\
\hline Bss $_{2}$ & $65-83$ & 8.2 & 0.3 & 0.4 & 05.6 & 87.8 & 17.9 & 160.2 & 17.5 & 14.84 & 07.08 & 0.352 & 3.240 & 0.61 \\
\hline $\mathrm{Bss}_{3}$ & $83-107$ & 8.5 & 0.3 & 0.4 & 06.3 & 85.9 & 17.9 & 155.5 & 11.2 & 16.04 & 04.35 & 0.416 & 4.274 & 0.59 \\
\hline $\mathrm{Cr}$ & $107-115$ & 8.0 & 0.3 & 0.4 & 27.0 & 75.2 & 16.8 & 210.1 & 13.7 & 16.02 & 04.13 & 0.416 & 4.430 & 0.23 \\
\hline
\end{tabular}


The available Mn content of these soils varied from 4.13 to $27.09 \mathrm{mg} \mathrm{kg}^{-1}$ soil. It was high in the surface horizons and gradually decreased with depth (except 1, 2 and 4 pedons), which might be due to its presence in the reduced forms in surface and subsurface layers and higher biological activity and organic carbon in the surface soils. These observations are in agreement with the findings of Murthy et al., (1997) and Nayak et al., (2000) and Rajeshwar and Ramulu, 2016. The DTPA extractable $\mathrm{Fe}$ content varied from 10.03 to $21.92 \mathrm{mg} \mathrm{kg}^{-1}$. According to critical limit of $4.5 \mathrm{mg} \mathrm{kg}^{-1}$ of (Lindsay and Norvell, 1978). The soils were sufficient in available iron. A decreasing trend with depth was noticed in (except 7) all pedons. It might be due to accumulation of humic material in the surface layers besides prevalence of reduced conditions in sub surface layers. The similar results were found by Nayak et al., (2000) and Prasad and Sakal (1991). Boron content varied from 0.21 to $1.32 \mathrm{mg} \mathrm{kg}^{-1}$. A decreasing trend with depth was noticed in (except 7) all pedons.

Studies undertaken to assess the horizon wise nutrient status regarding to the macro and micronutrients in soil profiles was found decreased with the depth of soils. Soils were very low to low in available $\mathrm{N}$, low to medium in available $\mathrm{P}$ and medium to high available $\mathrm{K}$ in the surface horizons and deficient to sufficient in $\mathrm{Zn}$ and sufficient in available $\mathrm{Cu}$, $\mathrm{Fe}, \mathrm{Mn}$ and $\mathrm{B}$ in the surface layers of the profiles.

\section{References}

Jalali, V.K., Talib, A.R. and Takkar, P.N. (1989). Distribution of micronutrients in some bench mark soils of Kashmir at different altitudes. J. Indian Soc. Soil Sci., 37: 465- 469.

Lindsay,W.L. and Norvell, W. A. (1978). Development of DTPA Soil test for zinc, iron, managenese and copper. Soil Sci. Soc. America J., 42: 421-428.

Murthy, I.Y.L.N.,Sastry, T.G., Datta, S.C., Narayanaswamy, G. and Rattan, R.K. (1997). Distribution of micronutruent cations in vertisols derived from different parent materials. J. Indian Soc. Soil Sci., 45, 577-580.

Nayak, D.C., Mukopadyay, S. and Sarkar, Deepak (2000). Distribution of some available micronutrients in alluvial soils of Arunachal Pradesh in relation to some charecterstics. J. Indian Soc. Soil Sci., 48: 612-614.

Pal, S.K. and Mukhopadyay, A.K. (1992). Distribution of different forms of potassium in profiles of some Entisols. J. Indian Soc. Soil Sci., 40: 371- 373.

Prasad, R. and Sakal, R. (1991). Availability of $\mathrm{Fe}$ in calcareous soils in relation to soil properties. J. Indian Soc. Soil Sci., 39: 658-661.

Prasuna, Rani, P., Pillai, R.N., Bhanuprasad, V. and Subbaiah G.V. (1992). Clay mineralogy of Alfisols and associated soils of Kavali area under Somasila project in Andhra Pradesh. J. Indian Soc. Soil Sci., 40 (4): 893-896.

Rajeshwar, M. and Ramulu, V. (2016). Vertical distribution of available macro $\&$ micronutrients in soil profiles of ganapavaram pilot area. An Asian Journal of Soil Science. 2 (1):202-206.

Sidhu, P.S., Rajkumar and Sharma, B.D. (1994). Characterization and classification of Entisols in different moisture regimes of India. J. Indian Soc. Soil Sci., 42 (4): 633640.

Thangaswamy, A., Naidu, M.V.S., Ramavatharam, M. and Raghavareddy, C. (2005).Char acterization, classification and evaluation of soil resources in Sivagiri micro- watershed of Chittoor district in Andhra Pradesh for sustainable land use planning. $J$. Indian Soc. Soil Sci., 53: 11-21. 
Ravte, S.S. (2008). Studies on status of available secondary nutrient and micronutrient anions in Ausa and Nilanga Tehsil of Latur District. M. Sc. (Agri) (Doctoral dissertation, Thesis submitted to Marathwada Agriculture University, Parbhani,(MS)
India).

Vijayakumar, R., Arokiaraj, A., \& Martin Deva Prasath, P. (2011). Macronutrient and micronutrients Status in relation to soil characteristics in South-East coast plain-riverine Soils of India. Oriental Journal of Chemistry, 27(2):567.

\section{How to cite this article:}

Ghode, M. K., P. H. Vaidya, Y. S. Pawar, S. A. Adkine and Bagmare, R. R. 2020. Vertical Distribution of Available Macro and Micronutrients in Cotton Growing Soils of Nanded District, Maharashtra. Int.J.Curr.Microbiol.App.Sci. 9(02): 3059-3064.

doi: https://doi.org/10.20546/ijcmas.2020.902.352 